\title{
Students' Perception on the Training of the Use Edmodo's E-Learning Application Media in Improving Students' English Writing Skill: Survey Research
}

\section{Candra Hadi Asmara}

The Lecturer of English Language Department, Faculty of Teacher Training Education, University of Muhammadiyah Gresik, Indonesia

(email: candrafkip@umg.ac.id)

\section{Amrin Batubara}

The Lecturer of English Language Department, Faculty of Teacher Training Education, University of Muhammadiyah Gresik, Indonesia

(email: amrinb77@gmail.com)

\section{Rizky Avira Dhea}

The Student of English Language Department, Faculty of Teacher Training Education, University of Muhammadiyah Gresik, Indonesia (email: rizkyaviradhea17@gmail.com)

\section{Article History}

Received: 27 January 2021

Reviewed: 10 February 2021

Accepted: 18 April 2021

Published: 27 April 2021

\section{Highlights}

Students find Edmodo a wonderful and user-friendly social learning platform that enables them to enjoy working on an online class especially in English writing skills
ABSTRACT: In Education 4.0 a vision of learning will form which will focus on how the sources of learning will be, then where and how students learn, so learning will become more meaningful while the teacher only acts as a facilitator in learning. However, achieving this vision is not easy, because there are still some problems found, related to the lack of use of technology in learning, and the lack of student knowledge in using technology as a support for the success of one learning. Based on the problems, the solution offered is Training of Utilizing Edmodo E-Learning Application Media to Improve Students' English Writing Ability. This research aims to investigate how the students of MA Masyhudiyah perceive the use of Edmodo as a media in English writing skills and how Edmodo helps the students in developing their writing ability. The participants were taken for the analysis as they fall under the Edmodo users. This research study used a quantitative method and a survey design was administered to gather a questionnaire with answers associated with a 5-point Likert scale ranging from strongly agree to strongly disagree. The survey was created using Google Form and was shared among the students through email and other sources. The result of the study shows that incorporating Edmodo enhances both student interest and motivation in English writing ability when particular Edmodo features are employed. The result through the analysis supports that the students have a positive perception using Edmodo is mainly towards for the resources, support and communication such as forum, discussions and also online activities. Students find Edmodo a wonderful and user-friendly social learning platform that enables them to enjoy working on an online class especially in English writing skills.

Keywords: Students' Perception, Technology in Learning, Edmodo Application 
Asmara, Batubara, and Dhea. Tell: Teaching of English Language and Literature Vol. 9, No.1, April - 2021 Doi: http://dx.doi.org/10.30651/tell.v9i1.7913

\section{Introduction}

Technology has been extensively integrated to facilitate teaching and learning activities. The emergence of it also encourages educators, teachers, and education practitioners to utilize technology for instructional aims. The development of information technology in the current era has changed the paradigm of society in seeking and obtaining information, which is marked by the emergence of the Industrial Revolution 4.0, which also affects the world of Education, where before this technology was initially carried out initially traditional but developed into a more modern era (Hussin, 2018). This development offers a program of comfort, flexibility and can be used for interactivity between users to be an advantage in the face of this technology, especially with E-Learning.

One of the technology types generated by the E-Learning activities is Edmodo. As a Learning Management System (LMS), Edmodo is widely applied nowadays. Since its emergence in 2008, designed by O'Hara and Borg, now it has been adopted by more than 81 million people all over the world (Scott, 2012; Hourdequin, 2014). Many people prefer to choose Edmodo because it has some other characteristics of Edmodo including its accessibility, connectivity, varied features, and low cost (Warawudhi, 2017) also encourage teachers to utilize it for advancing classroom instruction. Edmodo itself offers technologybased learning that has virtual classrooms that are certainly accessible to the entire school environment, such as teachers, students, and student guardians. According to Yanti et. al (2017), there are many benefits from using Edmodo, which can help students visualize abstract ideas and make it easy to find information, and also makes it easier for teachers to interact with students.

According to Cauley, Edmodo is an educational website that takes the ideas of a social network and refines them and makes them appropriate for a classroom. Duncan and Chandler (2011) also describe that Edmodo is a private social platform that provides a secure space for teachers and students to connect and collaborate. It enables the teacher and the students to be linked to each other so that the learning process can be integrated intensively. Moreover, teachers can also monitor their students' interactions. Edmodo can be applied easily in the classroom because the design of Edmodo is similar to Facebook that the students are familiar with. Based on those explanations about Edmodo, the use of Edmodo in this research is specifically as a media for the students to submit and publish their writing works where their friends can see and give suggestions towards their writings directly. Hopefully, the use of Edmodo can help the students to develop their writing skills. It was also supported by Al- 
Asmara, Batubara, and Dhea. Tell: Teaching of English Language and Literature Vol. 9, No.1, April - 2021 Doi: http://dx.doi.org/10.30651/tell.v9i1.7913

Naibi, Al-Jabri, and Al-Kabani (2018) that it was particularly useful to help develop students' writing skills.

Therefore, as the new strategy in teaching innovation-based technology, the feedback about Edmodo is very important. It encourages the students to share their ideas freely and without any limitations because they can always connect to them. In the process of using Edmodo for learning, the students may have different opinions; whether it helps them to develop their writing skill or not. However, the students who have a different opinion will have different responses towards the use of Edmodo in the learning process. The findings of this research can be a good evaluation of the use of Edmodo as a medium for teaching writing. Moreover, Tassinari (2010) as cited in Tassinari (2012, p. 30) has developed a framework for evaluating learner autonomy in foreign language learning which covers components, competencies, and strategies. It was later translated into a dynamic model for learner autonomy with descriptors for attitudes, skills, and learning behaviours.

The following researcher will discuss some aspects that divided into three parts; (1). the role of technology in e-learning, (2) the Edmodo as the selected platform that was going to be observed, and (3) the Edmodo as one of the media in teaching writing.

1. The Emergence of E-Learning in the era of digitizing technology

In the era of digitalization, technology has an influence on new lifestyles which can not be separated from electronic devices. Technology has a diversity of facilities and conveniences that can be felt by its users, especially in the Education sector. The presence of this technology is certainly welcomed by teachers to be able to use it as a media for learning which is certainly more innovative and creative than the use of non-technological media. Besides having a lot of positive effects on education, many people still don't know because they only focus on the technology used as entertainment media. Yet if judging deeper into technology they can use their best for success in learning.

One form of technological development is E-Learning. E-Learning is a form of innovation from technical information whose application focuses on the field of Education, where the model is designed in the form of cyberspace. Another term of E-Learning itself is the transformation of the learning process in schools or universities into a digital form that is bridged by internet technology (Munir, 2009: 169). According to Clark \& Mayer (2008: 10: 1). E-Learning itself emerged in 1970. There are various terms used in learning through technology including online learning, internet-enabled learning, virtual learning, or webbased learning. E-Learning has characteristics including; has content that is certainly very 
relevant to the learning objectives, uses learning methods, which presents examples of exercises that can enhance learning, uses visual media and graphics to deliver learning material, can enable direct learning centred on the teacher (synchronous learning) or can be designed to independent learning (e-learning asynchronous), and the last can build understanding and skills related to learning goals both individually and improve learning performance in groups. One example of E-Learning is Edmodo.

2. Edmodo as one of the concrete proofs of e-learning platform technology

According to Jarc (2010), Edmodo is an E-Learning platform that provides services to make it easier for students to manage their accounts only for their students. Edmodo was first designed by Jeff O'Hara and Nick Borg in 2008. The Edmodo site has a much safer application compared to other E-Learning besides, Nick Borg \& O'Hara (2008) also believes that with Edmodo students will be more easily explore learning more broadly through technology, one of which can facilitate students to be able to share content, collect homework, quizzes, discussions or can provide feedback. Bates (2005) also added that the simplicity of Edmodo to be an application in learning, especially writing, would be very likely to be accepted by students. Besides Edmodo is also considered to be able to facilitate teachers in utilizing this media in the teaching and learning process, so that later it is expected that with the application of this media, teachers will better utilize the use of technology and types of media. The use will be more varied. And more important is the understanding that the use of Edmodo in the teaching process towards students also needs to be emphasized, so students can optimize the use of this technology as something they can use for the educational learning process for them.

\section{Edmodo as a learning media in writing}

The use of Edmodo media for writing is one thing that is believed to have a more effective effect than the use of traditional media (Shams-abadi et al, 2015). This can be seen according to previous research which has proven that Edmodo can work optimally in writing classes ( Fennel \& Bakir, 2013; Gardner, 2013; Pop, 2013; Karyawati, 2014; Abadi, Ahmadi \& Mehrdad, 2015). Among the research conducted by Abadi \& Merdad in 2015 which in his research revealed that students who participated in learning in the Edmodo group had better writing results than participants who did not use Edmodo. In the following year also Fauzi (2017) conducted a study of Edmodo's effectiveness in the ability to write students also had results that were no less surprising, where the results of the student's pre-test and post-test showed a very significant difference, namely the results of the student's post-test were considered to be very good and more improved, so it can also be said that Edmodo has a 
tremendous impact on the development of student's writing skills, besides that the interaction between students through Edmodo can hone their abilities so that they will form sentences which certainly can be well structured too.

\section{Method}

The methodology used in this research is quantitative research with a survey design. According to Ary, Jacobs, Sorensen, and Razavieh (2010), quantitative research is research which deals with questions of relationship, cause and effect, or current status that researchers can answer by gathering and analyzing the numeric data. Quantitative research may be further divided into either experimental or non-experimental. This research specifically the quantitative research was classified as non-experimental quantitative research because the researcher conducted a survey method to investigate the answer to the research questions.

Moreover, based on Babbie's perspective (1973), surveys are frequently conducted to make descriptive assertions about some population: discover the distribution of certain traits or attributes. In this regard, the researcher is not concerned with why the observed distribution exists, but merely what that distribution is. A survey may involve observation of respondent's behaviour, or evidence of such behaviour, in conjunction with or separately from the asking question. Therefore, the survey method is always concerned with the behavioural members of the population of interest. Ary et al. (2010, p. 372) state that in the survey method, investigators ask questions about peoples' beliefs, opinions, characteristics, and behaviour. In Survey, the researcher allows to conclude the characteristics of different groups or to measure their attitudes and opinions toward some topics. Thus, the survey was also used to identify the students' perception of the use of Edmodo in English writing skills.

\section{Research Participants}

In this case, the total population was 110 respondents who came from the $1^{\text {st }}$ grade of MA Masyhudiyah students. They were the students who had studied recount and report text by using Edmodo. To gather the data from the questionnaire, the researcher selected 71 students as the sample. Therefore, a sample is a portion of the population. The sample used for collecting the data from the questionnaire was used purposive sampling. Purposive sampling is one of the samplings that is classified based on the knowledge of a population and the purpose of the research. The subjects were selected because of some characteristics. As supported by Ary et al. (2010, p. 156) state that purposive sampling is also referred to as judgment sampling; sample elements judged to be typical, or representative, is chosen from the population. The researcher determined 30 students as the sample in this case because they had the same classification to be a respondent, then the researcher also considered that those 
students had implemented Edmodo in writing some of the texts. So, the researcher chooses those 71 students as the research participants who fulfilled the requirements and give some information needed.

\section{Research Instrument}

The instrument used here is the questionnaire to obtain the data based on the respondent's feedback towards the questions given. The results of this questionnaire will be used as the main data of this research.

In this research, the researcher developed this questionnaire based on Likert-type items. According to Ary et al. (2010), Likert types let the respondents indicate their responses to select statements on a continuum. In other words, the respondents should choose the statements based on the scale that is provided. In this research, the questionnaire responded to number one to four. The number indicated whether they strongly disagree, disagree, agree, or strongly agree. Moreover, there were two items in developing the questionnaire; they were positive and negative items. The researcher used positive items to avoid the respondents' answer set influences. the answer categories must be weighted. Both positive and negative items had different score for each scale because negatively stated items, the weighting was reversed because disagreement with a disapproval statement was psychologically equivalent to an agreement with an approval statement. Here, the scale of the score in detail:

Table 1

The score distribution

\begin{tabular}{|c|c|}
\hline \multicolumn{2}{|c|}{ Positive Statements } \\
\hline Strongly Disagree & 1 \\
\hline Disagree & 2 \\
\hline Agree & 3 \\
\hline Strongly Agree & 4 \\
\hline
\end{tabular}

(Source : Ary et al., 2010, p. 210)

\section{Data Analysis Technique}

After gaining the data, firstly, the researcher was tabulating the data gathered in the SPSS application and secondly, the researcher interpreting the data into the descriptive analysis. In this case, the researcher tabulated the data in form of data frequency and data percentage. After the researcher gained the data from the questionnaire and knew the degree of students' responses in scale, which strongly disagreed, disagree, agree, and strongly agree. Then, the 
researcher calculated the number of each statement into percentage used a formula to know the score of each scale in percentage. The formula is shown in the formula below:

$$
\frac{\sum x}{\sum n} \times 100 \%
$$

$\sum x=$ Number of students that choose the same scale in each statement

$\sum n=$ Amount of the students

After the researcher computed the mean, the researcher presents the result firstly per part. Then, the researcher interprets per item in each category based on the data acquired from the questionnaire.

\section{Research Procedure}

Some steps in implementing the survey method can be seen on the following chart:

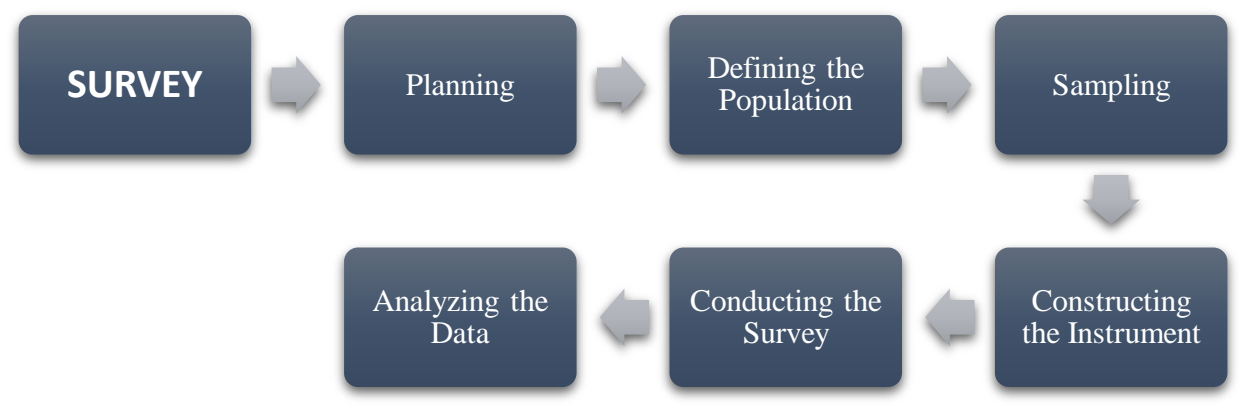

Based on the chart above, it can be explained as follows:

\section{Planning}

Before determining the research, the researcher started to create a question that the researcher believed could be answered appropriately using the survey method. The researcher defined the questions in this research, they are: "What is the students" perception on the use of Edmodo in writing English Writing Skills?"

\section{Defining the Population}

This step is one of the crucially important steps in conducting the survey. The researcher must define the population for the subject; to whom the survey will be conducted. The total population of this research was 110 students who became Edmodo users and has implemented Edmodo for E-Learning.

\section{Sampling}

The sample is a smaller group than the population. On the other hand, the sample must be representative of the population. The researcher chose 71 students from the total population as the sample and also as the participants for gathering the data from the questionnaire and the researcher used the technique of purposive sampling 
Asmara, Batubara, and Dhea. Tell: Teaching of English Language and Literature

Vol. 9, No.1, April - 2021 Doi: http://dx.doi.org/10.30651/tell.v9i1.7913

\section{Constructing the Instruments}

A major task in the survey method is constructing the instrument that will be used to gather the data from the sample. After the researcher defined the students as the participants, the researcher began to construct the instrument. It can be a questionnaire, interview, or observation as well.

\section{Conducting Survey}

In this step, the researcher started to distribute the instrument and share it with a participant who becomes respondents to obtain the information.

\section{Analyzing the Data}

The last step in the survey method procedure is consists of coding the data, statistical analysis, summarizing the results, and concluding the findings. So in this step, the researcher processed the data gained from the instruments. After that, the researcher reported the research finding and drew the conclusion based on the finding in this research.

\section{Results}

\section{Discussions, Conclusion, and Recommendations}

The result of students' perception of Edmodo E-Learning Application Media to Improve Students' Writing Ability held at MA Masyhudiyah was attended by 71 participants. The details can be shown in the table below:

\section{Table 2}

Number of student attendances

\begin{tabular}{|l|l|l|}
\hline No. & Gender & Total \\
\hline 1. & Male & 37 \\
\hline 2. & Female & 34 \\
\hline & Total & 71 \\
\hline
\end{tabular}


Asmara, Batubara, and Dhea. Tell: Teaching of English Language and Literature

Vol. 9, No.1, April - 2021 Doi: http://dx.doi.org/10.30651/tell.v9i1.7913

From those amount of the students, the researcher has already gained the results of their responses and below are the findings of the questionnaire answered by respondents with the frequency, percentage, mean, standard deviation and level of interpretation:

Table 3.

Perception towards the use of Edmodo in improving students' English writing skills

\begin{tabular}{|c|c|c|c|c|c|c|c|c|}
\hline \multirow{2}{*}{ No } & \multirow{2}{*}{ Statement } & \multicolumn{4}{|c|}{ Frequency and Percentage } & \multirow{2}{*}{ Mean } & \multirow{2}{*}{ Std. } & \multirow{2}{*}{ Level } \\
\hline & & $\mathrm{SD}$ & $\mathrm{D}$ & $\mathrm{A}$ & $\mathrm{SA}$ & & & \\
\hline 1 & $\begin{array}{l}\text { I believe that learning } \\
\text { English is important for me } \\
\text { especially in writing. }\end{array}$ & $\begin{array}{c}4 \\
5.6 \%\end{array}$ & $\begin{array}{c}8 \\
11.3 \%\end{array}$ & $\begin{array}{c}40 \\
56.3 \%\end{array}$ & $\begin{array}{c}19 \\
26.8 \%\end{array}$ & 3.73 & .7359 & + \\
\hline 2 & $\begin{array}{l}\text { I am interested in writing } \\
\text { English. }\end{array}$ & $\begin{array}{c}4 \\
5.6 \%\end{array}$ & $\begin{array}{c}4 \\
5.6 \%\end{array}$ & $\begin{array}{c}36 \\
50.7 \%\end{array}$ & $\begin{array}{c}27 \\
38 \%\end{array}$ & 3.56 & .6914 & + \\
\hline 3 & $\begin{array}{l}\text { My writing skill in English } \\
\text { is good enough after using } \\
\text { Edmodo }\end{array}$ & $\begin{array}{c}7 \\
9.9 \%\end{array}$ & $\begin{array}{c}2 \\
2.8 \%\end{array}$ & $\begin{array}{c}30 \\
40.2 \%\end{array}$ & $\begin{array}{c}32 \\
45.1 \%\end{array}$ & 3.40 & .7086 & + \\
\hline 4 & $\begin{array}{l}\text { I always try to make a good } \\
\text { writing using Edmodo }\end{array}$ & $\begin{array}{c}3 \\
4.2 \%\end{array}$ & $\begin{array}{c}10 \\
14.1 \%\end{array}$ & $\begin{array}{c}31 \\
43.7 \%\end{array}$ & $\begin{array}{c}27 \\
38.0 \%\end{array}$ & 3.56 & .8574 & + \\
\hline 5 & $\begin{array}{l}\text { I use the Internet to help me } \\
\text { do my assignment in writing } \\
\text { text }\end{array}$ & $\begin{array}{c}5 \\
7 \%\end{array}$ & $\begin{array}{c}12 \\
16.9 \%\end{array}$ & $\begin{array}{c}26 \\
36.6 \%\end{array}$ & $\begin{array}{c}28 \\
39.4 \%\end{array}$ & 3.36 & .8491 & - \\
\hline 6 & $\begin{array}{l}\text { I agree with using Edmodo } \\
\text { as a media in the learning } \\
\text { process. }\end{array}$ & $\begin{array}{c}4 \\
5.6 \%\end{array}$ & $\begin{array}{c}12 \\
16.9 \%\end{array}$ & $\begin{array}{c}18 \\
25.4 \%\end{array}$ & $\begin{array}{c}37 \\
52.1 \%\end{array}$ & 3.46 & .8422 & + \\
\hline 7 & $\begin{array}{l}\text { I have known Edmodo } \\
\text { before E-learning }\end{array}$ & $\begin{array}{c}6 \\
8.5 \%\end{array}$ & $\begin{array}{c}11 \\
15.5 \%\end{array}$ & $\begin{array}{c}20 \\
28.2 \%\end{array}$ & $\begin{array}{c}34 \\
47.9 \%\end{array}$ & 3.49 & .8597 & + \\
\hline 8 & $\begin{array}{l}\text { I am interested to use } \\
\text { Edmodo in English writing } \\
\text { learning }\end{array}$ & $\begin{array}{c}9 \\
12.7 \%\end{array}$ & $\begin{array}{c}8 \\
11.3 \%\end{array}$ & $\begin{array}{c}30 \\
42.3 \%\end{array}$ & $\begin{array}{c}24 \\
33.8 \%\end{array}$ & 3.74 & .8595 & + \\
\hline 9 & $\begin{array}{l}\text { I often access Edmodo to } \\
\text { increase my writing skills }\end{array}$ & $\begin{array}{c}7 \\
9.9 \%\end{array}$ & $\begin{array}{c}11 \\
15.5 \%\end{array}$ & $\begin{array}{c}38 \\
53.5 \%\end{array}$ & $\begin{array}{c}15 \\
21.1 \%\end{array}$ & 3.52 & .8403 & + \\
\hline 10 & $\begin{array}{l}\text { I believe that Edmodo is } \\
\text { easy to use. }\end{array}$ & $\begin{array}{c}11 \\
15.5 \%\end{array}$ & $\begin{array}{c}7 \\
9.9 \%\end{array}$ & $\begin{array}{c}28 \\
39.4 \%\end{array}$ & $\begin{array}{c}29 \\
40.8 \%\end{array}$ & 3.40 & .9036 & + \\
\hline 11 & $\begin{array}{l}\text { I believe that Edmodo is a } \\
\text { familiar educational website } \\
\text { to improve English writing } \\
\text { skills }\end{array}$ & $\begin{array}{c}11 \\
15.5 \%\end{array}$ & $\begin{array}{c}16 \\
22.5 \%\end{array}$ & $\begin{array}{c}29 \\
40.8 \%\end{array}$ & $\begin{array}{c}15 \\
21.15\end{array}$ & 3.67 & .9823 & + \\
\hline 12 & $\begin{array}{l}\text { I believe that Edmodo } \\
\text { makes me easier to learn } \\
\text { English. }\end{array}$ & $\begin{array}{c}7 \\
9.9 \%\end{array}$ & $\begin{array}{c}15 \\
21.1 \%\end{array}$ & $\begin{array}{c}24 \\
33.8 \%\end{array}$ & $\begin{array}{c}25 \\
21.1 \%\end{array}$ & 3.67 &. .9223 & + \\
\hline
\end{tabular}


Asmara, Batubara, and Dhea. Tell: Teaching of English Language and Literature Vol. 9, No.1, April - 2021 Doi: http://dx.doi.org/10.30651/tell.v9i1.7913

\begin{tabular}{|c|c|c|c|c|c|c|c|c|}
\hline 13 & $\begin{array}{l}\text { I believe that Edmodo is an } \\
\text { effective educational } \\
\text { website to help me in } \\
\text { writing text. }\end{array}$ & $\begin{array}{c}11 \\
15.5 \%\end{array}$ & $\begin{array}{c}13 \\
18.3 \%\end{array}$ & $\begin{array}{c}30 \\
42.3 \%\end{array}$ & $\begin{array}{c}17 \\
23.9 \%\end{array}$ & 3.74 & 9959 & + \\
\hline 14 & $\begin{array}{l}\text { Using Edmodo make me } \\
\text { easier get the feedback and } \\
\text { suggestion from teacher and } \\
\text { friends }\end{array}$ & $\begin{array}{c}10 \\
14.1 \%\end{array}$ & $\begin{array}{c}10 \\
14.1 \%\end{array}$ & $\begin{array}{c}18 \\
25.4 \%\end{array}$ & $\begin{array}{c}33 \\
46.5 \%\end{array}$ & 3.60 & .9020 & + \\
\hline 15 & $\begin{array}{l}\text { I get more motivated to } \\
\text { increase my English } \\
\text { writings skills by using } \\
\text { Edmodo. }\end{array}$ & $\begin{array}{c}5 \\
7 \%\end{array}$ & $\begin{array}{c}11 \\
15.5 \%\end{array}$ & $\begin{array}{c}26 \\
36.6 \%\end{array}$ & $\begin{array}{c}29 \\
40.8 \%\end{array}$ & 3.60 & .8860 & + \\
\hline 16 & $\begin{array}{l}\text { I feel enthusiastic to learn } \\
\text { when I am using Edmodo. }\end{array}$ & $\begin{array}{c}6 \\
8.5 \% \\
\end{array}$ & $\begin{array}{c}18 \\
25.4 \% \\
\end{array}$ & $\begin{array}{c}19 \\
26.8 \% \\
\end{array}$ & $\begin{array}{c}28 \\
39.4 \% \\
\end{array}$ & 3.82 & .9151 & + \\
\hline 17 & $\begin{array}{l}\text { I believe that Edmodo is a } \\
\text { fun educational website to } \\
\text { learn English especially for } \\
\text { writing skill. }\end{array}$ & $\begin{array}{c}3 \\
4.2 \%\end{array}$ & $\begin{array}{c}8 \\
11.3 \%\end{array}$ & $\begin{array}{c}25 \\
35.2 \%\end{array}$ & $\begin{array}{c}35 \\
49.3 \%\end{array}$ & 3.67 & .7324 & + \\
\hline 18 & $\begin{array}{l}\text { I believe that using Edmodo } \\
\text { can help me to develop my } \\
\text { skill in writing text } \\
\text { (grammar accuracy and } \\
\text { spelling). }\end{array}$ & $\begin{array}{c}4 \\
5.6 \%\end{array}$ & $\begin{array}{c}15 \\
21.1 \%\end{array}$ & $\begin{array}{c}31 \\
43.7 \%\end{array}$ & $\begin{array}{c}21 \\
29.6 \%\end{array}$ & 3.31 & .9349 & - \\
\hline 19 & $\begin{array}{l}\text { I believe that Edmodo is } \\
\text { beneficial as a media for } \\
\text { English learning } \\
\text { specifically for writing }\end{array}$ & $\begin{array}{c}10 \\
14.1 \%\end{array}$ & $\begin{array}{c}7 \\
9.9 \%\end{array}$ & $\begin{array}{c}26 \\
33.6 \%\end{array}$ & $\begin{array}{c}28 \\
39.4 \%\end{array}$ & 3.57 & .8562 & + \\
\hline 20 & $\begin{array}{l}\text { I am satisfied to write } \\
\text { English text using Edmodo. }\end{array}$ & $\begin{array}{c}2 \\
2.8 \% \\
\end{array}$ & $\begin{array}{c}13 \\
18.3 \%\end{array}$ & $\begin{array}{c}24 \\
33.8 \% \\
\end{array}$ & $\begin{array}{c}32 \\
45.1 \%\end{array}$ & 3.78 & .7730 & + \\
\hline
\end{tabular}

There are 20 statements in the questionnaire about perception towards the use of Edmodo in improving students' English writing skills. It is consists of three groups in this finding. The first is about the benefit of Edmodo, the second is about the effects of Edmodo, and the last is about students' experiences on the use of Edmodo. These scores indicate that perception towards the use of Edmodo in improving students' English writing skills mostly in positive level, it means that students have a positive perception towards the use of Edmodo in the teaching and learning process. The lowest mean is showed in the Eighteenth statement with a mean score of 3.31, which include in negative level. The highest mean is showed in the sixteenth statement with a mean score of 3.82 , it is at a positive level. 
Asmara, Batubara, and Dhea. Tell: Teaching of English Language and Literature Vol. 9, No.1, April - 2021 Doi: http://dx.doi.org/10.30651/tell.v9i1.7913

From 20 statements, the majority 18 statements mentioned that most students' perception towards the use of Edmodo in the teaching and learning process is positive. It can be seen from the result of the questionnaire that has filled by students. In this study, the researcher found that students agree that Edmodo is a media in English learning to improve their writings skills. There are some benefits of Edmodo that give a positive contribution to students' learning. According to Jones (2010), one of the benefits of Edmodo is it provides quick and easy access to assignments, polls, calendars, and other information on the web. Additionally, Owston (1997) have observed that the students can study online independently, communicate with the facilitator or lecturer, and submit assignments anywhere and anytime based on the schedule that is determined by the lecturer.

Based on the analysis of the data gained and the discussion on the results, the researcher found that most of the students had a positive response towards the implementation of Edmodo in writing text. Most of the students were interested to use Edmodo in learning English, especially in writing text. It is proven by the result obtained from the data that the students are happy when they are using Edmodo for English writings skills. Moreover, the students believe that Edmodo is easy to use even Edmodo is still new for them; they agreed that the procedure about the use of Edmodo can be followed easily. Then, it was determined that the use of Edmodo gave a positive impact on the students' writing. Based on the research question, the use of Edmodo helped the students to increase their writing skills through writing text. Moreover, it also helped the students in correcting their writing skills included their grammar accuracy and spelling. Using Edmodo enhanced the students' self-expression and self-confidence in writing text. Using Edmodo also encouraged the students to learn and practice writing because they could share about their writing works and giving suggestions to each other to have good writing. Besides that, the teacher could also give the suggestion and feedbacks toward the students' writing works and the students could revise their writing easily to make it better. According to the personal feelings, the students perceived that they felt interested, happy, enjoy, motivated, and satisfied to use Edmodo as a media to improve students' English writing skills.

\section{References}

Abadi, B. B. S., Ahmadi, S \& Mehrdad, A. G. (2015). The Effect of Edmodo on EFL Learners' Writing Performance. International Journal of Educational Investigations (ISSN: 2410-3446) Almubark (2016) Exploring The Problems Faced By The Teachers In Developing English Writing Skills For The Students In Saudi Arabia. International Journal of English Language Teaching Vol.4, No.10, pp.10-23, December 2016 
Asmara, Batubara, and Dhea. Tell: Teaching of English Language and Literature Vol. 9, No.1, April - 2021 Doi: http://dx.doi.org/10.30651/tell.v9i1.7913

Al-Naibi, I., Al-Jabri, M., \& Al-Kalbani, I. (2018). Promoting Students' Paragraph Writing using Edmodo: An Action Research. TOJET: The Turkish Online Journal of Educational Technology. 17(1), 130-143

Ary, D., Jacobs, L. C., Sorensen, C., \& Razavieh, A. (2010). Introduction to research in education (8th ed.). Boston: Wadsworth, Cengage Learning.

Babbie, E. R. (1973). Survey research methods. Belmont, CA: Wadsworth Publishing Company.

Chandler, Curtis. (2015). Four tools to help gamify your classroom. Middle web. https://www.middleweb.com/tag/gamification-in-the-classroom/

Fauzi, A. 2017 The Effect of Edmodo on Students' Writing Skill in Recount Text. International Journal of Pedagogy and Teacher Education (IJPTE) (Vol.1 Issue 2 | October 2017)

Jarc, C. (2010). Edmodo a free web 2.0 classroom management tool. http://trendingeducation.com/? Retrieved on November 7, 2015

Mayer, R. E. (2008). Teaching by priming students' motivation to learn. In

R. E. Mayer (Ed.), Learning and instruction (pp. 458 -522). Upper

Saddle River, NJ: Pearson Education.

Mayer, R. E. (2008). Teaching by priming students' motivation to learn. In

R. E. Mayer (Ed.), Learning and instruction (pp. 458 -522). Upper

Saddle River, NJ: Pearson Education.

Mayer, R. E. (2008). Teaching by priming students' motivation to learn. In R. E. Mayer (Ed.), Learning and instruction (pp. 458 -522). Upper Saddle River, NJ: Pearson Education.

Muller \& Louw (2004) Learning Environment, motivation and interest: Perspectives on selfdetermination theory. South African Journal Psychology 2004, 34 (2), pp. 1-22

Munir. (2009). Pembelajaran jarak jauh berbasis teknologi informasi dan komunikasi. Bandung: Alfabeta.

Scott, M. (2012). Go Ahead...Be Social: Using Social Media to Enhance the Twenty-First Century Classroom. Distance Learning. 9(2), 54-59.

Tassinari, M.G. (2012). Evaluating Learner Autonomy: A dynamic Model with Descriptors. SiSAL Journal. 3(1), 24-40. [26]

Tassinari, M. G. (2015). Assessing Learner Autonomy: A Dynamic Model. In: Everhard, Carol J. \& Murphy, Linda (Eds): Assessment and Autonomy in Language Learning. 64-88. Basingstoke: Palgrave Macmillan. DOI: 10.1057/9781137414380_4

Warawudhi, R. (2017). The Evaluation of Edmodo in Business Reading Class. International Journal of Information and Education Technology. 7(2), 153-158. 